ДОСЛІДЖЕННЯ ОСОБИСТІСНИХ ОСОБЛИВОСТЕЙ СТУДЕНТІВ-ФУТБОЛІСТІВ У КОНТЕКСТІ ҐЕНДЕРНИХ ВІДМІННОСТЕЙ ТА СОЦІАЛІЗАЦІї

\title{
RESEARCH OF PERSONAL FEATURES OF STUDENTS-FOOTBALL PLAYERS IN THE CONTEXT OF GENDER DIFFERENCES AND SOCIALIZATION
}

У статті розелядаються питання вивчення проблеми статевих відмінностей психіч ної організації спортсменів. Відомо, що у багатьох спортсменок умовно чоловічих видів спорту спостерігаються труднощі в ґендерній ідентисрікації особистості. Мета статті - провести діагностику та дослідження за окремими психологічними методиками (Т. Елерса та Дж. Роттера) особистісних особливостей студентів-фрутболістів 3 урахуванням ґендерних особливостей. Були використані такі методи дослідження: аналіз та узагальнення літературних джерел і інтернет-ресурсів з досліджуваної проблеми, анкетування, опитування. Були використані такі психологічні методи: методика T. Елерса «Діагностика особистісної мотивації до успіху», методика «Рівень суб'єктивного контролю (РСК)» Дж. Роттера, а також методи математичної статистики. За результатами проведення методики Т. Елерса «Діагностика особистісної мотивації до успіху» ми виявили, що у групі юнаків більшість піддослідних (38,09\%) має помірно високий рівень мотивації до досягнення успіху, у 33,5\% піддослідних був виявлений високий рівень мотивації, у 21,42\% - середній, у 7,14\% - низький. У дівчат-срутболісток переважає середній рівень мотивації. Він становить 40,54\%. 21,62\% дівчат мають низький рівень мотивації до досягнення успіху, 27,02\% - помірно високий, 10,82\% - високий рівень. Таким чином, можна побачити за отриманими результатами різницю в групах спортсменів у досягненні цілей $з$ урахуванням їхньої статі. Група юнаків-футболістів більше мотивована на успіх, ніж група дівчат. Аналіз результатів дослідження з методики «Рівень суб'єктивного контролю (РСК)» Дж. Роттера показав, що високі показники за цією шкалою, а саме 100\% випробовуваних першої групи та 67\% випробовуваних другої, відповідають високому рівню суб'єктивного контролю над емоційно-позитивними подіями та ситуаціями. Такі спортсмени вважають, що вони досягли всього хорошого, що було $і \epsilon$ в їхньому житті, і що вони здатні досягти поставленої мети в майбутньому. Ще один фрактор, який впливає на рівень тривожно- cmi, - че стать випробовуваних. Результати проведеного дослідження показали, що дівчата-фуртболістки тривожніші, ніж спортсмени-юнаки.

Ключові слова: ґендерні відмінності, студентський спорт, футбол, соціалізація спортсменів.

The article considers the study of the problem of gender differences in the mental organization of athletes. It is known that many athletes of conventionally male sports have difficulties in gender identification. Purpose: diagnosis and research according to separate psychological methods (T. Ehlers and J. Rotter) of personal features of football students taking into account gender features. Research methods. The following research methods were used: analysis and generalization of literature sources and Internet resources on the researched problem; questionnaires; poll; psychological methods: T. Ehlers' method "Diagnosis of personality motivation for success"; J. Rotter's method "Level of subjective control"; methods of mathematical statistics. According to the results of the method of T. Ehlers "Diagnosis of personality motivation for success" in the group of young men, the majority of subjects (38.09\%) have a moderately high level of motivation to succeed, $33.5 \%$ of subjects showed a high level of motivation, $21,42 \%$ - medium and $7,14 \%$ - low, 21,62\% have a low level, 27,02\% are moderately high and $10.82 \%$ have a high level of motivation to succeed. Thus, it is possible to see the difference in the groups of subjects in achieving goals based on the sex of athletes, a group of young football players is more motivated to succeed than a group of girls. J. Rotter showed that high scores on this scale, namely $100 \%$ of subjects in the first group and $67 \%$ in the second, correspond to a high level of subjective control over emotionally positive events and situations. Such athletes believe that they have achieved all the good that has been and is in their lives, and that they are able to successfully pursue their goals in the future. Another factor that affects the level of anxiety is the gender of the subjects. The results of the study showed that girls - football players are more anxious than boys - athletes. Key words: gender differences, student sports, football, socialization of athletes.
Відомо, що на початкових етапах спортивної кар'єри, у дитинстві, а також у дорослому житті та після завершення спортивної кар'єри спостерігається ідентифікація спортсменів [1, с. 7; 3, с. 144]. Спортсменкам, які вибрали умовно чоловічі види спорту (наприклад, футбол, важку атлетику, дзюдо, таеквондо, гирьовий спорт тощо), досить часто приписуються маскулінні якості з погляду поведінки та морфології [2, с. $114 ; 5$, с. 10].

Для спортивної діяльності маскулінні якості перебувають у пріоритеті та позитивно впливають на спортивний результат. Проте маскулінність може обмежувати ефективність міжособистісних взаємовідносин поза спортивною діяльністю [8, с. 117].

Згідно 3 даними окремої науково-методичної літератури у багатьох спортсменок умовно чоловічих видів спорту спостерігаються труднощі в ґендерній ідентифікації, зокрема і в особистому житті. Вони спостерігають у себе зайву агресивність у спілкуванні та поведінці [4, с. 27; 7, с. 52].

Проблема формування маскулінності та фемінінності викликає багато суперечок та розбіжностей, зокрема у питанні про те, чи 
$€$ даний особистісний компонент уродженим або він $є$ набутим у ході розвитку особистості $[9$, c. $71 ; 12$, с. 106].

Відомо, що спорт є однією з високоспецифічних сфер діяльності людини. На думку багатьох фахівців, він активно сприяє формуванню ґендерних якостей особистості [3, с. 146].

У зв'язку з розширенням діапазону жіночого спорту останнім часом ця тематика загострилася. Жінки змагаються у тих видах спорту, які донедавна вважалися чоловічими. Такі види спорту змушують представниць прекрасної статі виявляти нетипові особливості поведінки. Відомо, що сильна ідентифікація спортсменів із їхньою спортивною роллю починається в ранньому дитинстві та супроводжує їхнє подальше життя [6; 10, с. 118].

Фахівці довели необхідність урахування ґендерної ролі під час судження про ті чи інші відмінності між спортсменами та спортсменками, про вплив спорту на особистість жінок порівняно з чоловіками [11, с. 130]. Проте наявні експериментальні викладки були зроблені без урахування особливостей спортивної діяльності, що суттєво знижує їхню цінність.

Ми вважаємо, що певні знання процесу формування та становлення ґендерної ідентичності спортсменок можуть дозволити розробити загальні принципи психологічної роботи з жіночим складом.

Мета дослідження - провести діагностику за окремими психологічними методиками (Т. Елерса та Дж. Роттера) особистісних особливостей студентів-футболістів з урахуванням ґендерних особливостей.

Ми використали такі методи дослідження, як: аналіз та узагальнення літературних джерел і інтернет-ресурсів з досліджуваної проблеми, анкетування, опитування; психологічні методи (методика Т. Елерса «Діагностика особистості мотивації до успіху», методика «Рівень суб'єктивного контролю (РСК)» Дж. Роттера); методи математичної статистики.

У спортивній діяльності розвиваються всі психічні процеси та якості особистості людини. Це такі якості: інтелектуальні, що забезпечують прийом та переробку інформації, прийняття рішень; психомоторні, що визначають якість рухових процесів; емоційні, що впливають на енергетику та експресивні характеристики діяльності; вольові, що забезпечують подолання перешкод, які виникають; комунікативні, створені задля взаємодії з іншими людьми; моральні, що визначають мотивацію діяльності [13, с. 109].

Однак далеко не всі психічні якості чітко поділяються на чоловічі та жіночі. Крім того, виявилося, що співвідношення «маскулінність / фемінінність» за різними шкалами може бути різним: людина, маскулінна за одними показниками, може бути фемінінною за іншими.
Проблема статевих відмінностей психічної організації людини завжди становила великий інтерес для дослідників. Однак, попри це, досі залишається безліч невирішених проблем.

Спорт - один із видів діяльності, що має низку специфічних особливостей. Традиційний для чоловіків процес соціалізації більшою мірою, ніж для жінок, передбачає заняття спортом. Досі існують певні види спортивної діяльності, які характеризуються як кращі для чоловіків або жінок [10, с. 160].

$€$ деякі відмінності у прояві особами чоловічої та жіночої статі інтересу до різних видів спорту. Хлопчики значно частіше цікавляться волейболом, баскетболом, футболом та хокеєм, дівчатка - фігурним катанням та гімнастикою. Що стосується інтересу до легкої атлетики і плавання, то тут відмінностей немає [11, с. 24].

Прагнення багатьох жінок освоїти всі види спорту, якими займаються чоловіки, зумовлене бажанням довести свою соціальну рівноправність та біологічну повноцінність. Жінки стали займатися «чоловічими» видами спорту - важкою атлетикою, різними видами боротьби, хокеєм з шайбою, регбі, футболом, водним поло, марафонським бігом тощо $[10$, c. 120$]$.

Численні дослідження довели вплив спорту на особистість людини, яка ним займається. Крім того, є деякі дані про вплив спорту на особистість жінок порівняно з чоловіками. Однак питання формування якостей особистості в маскулінних та фемінінних видах спорту вивчене недостатньо.

Бальні танці, фігурне катання -це парні види спорту, де розділені функції чоловіка та жінки у досягненні єдиної мети, тобто максимального прояву технічної майстерності й емоційної виразності. Партнерка репрезентує образ краси, яскравості, м'якості та жіночності [3, с. 150].

На відміну від тих підлітків, які не займаються спортом, у представників фемінінного виду розвиваються такі особливості особистості: у дівчаток - домінантність, конформізм, самоконтроль, андрогінний тип особистості з великим набором фемінінних характеристик; у хлопчиків - домінантність.

Н.Г. Цикунова (2003) зазначає, що спорт не деформує особистість, не перетворює ії з фемінінної на маскулінну чи навпаки, він сприяє формуванню андрогінної структури. Виявлені особливості визначаються вимогами спортивної спеціалізації [10, с. 88].

У спорті традиційне порівняння чоловіків і жінок за генетичною статтю і без урахування маскулінності та фемінінності не відповідає реальності, яка полягає в наявності статевих типів, а не тільки статей. Під час порівняння маскулінних чоловіків та жінок, а також 
фемінінних чоловіків та жінок виходять зовсім інші результати, ніж під час порівняння маскулінних чоловіків та фемінінних жінок.

У нашому дослідженні взяло участь 120 осіб віком від 18 до 26 років, з них - 54 юнаки та 66 дівчат. За результатами проведення методики Т. Елерса «Діагностика особистісної мотивації до успіху» були отримані дані, представлені у табл. 1 .

Таблиця 1

\section{Розподіл показників}

студентів-футболістів обох статей за рівнем мотивації до досягнення успіху

\begin{tabular}{|c|c|c|c|c|c|}
\hline \multirow{2}{*}{$\begin{array}{c}\text { Рівні } \\
\text { мотивації }\end{array}$} & \multicolumn{2}{|c|}{$\begin{array}{l}\text { Юнаки } \\
(n=42)\end{array}$} & \multicolumn{2}{|c|}{$\begin{array}{c}\text { Дівчата } \\
(n=37)\end{array}$} & \multirow{2}{*}{\begin{tabular}{|c|} 
Достовір- \\
ність \\
відмінностей
\end{tabular}} \\
\hline & $\%$ & $\mathbf{n}$ & $\%$ & $\mathbf{N}$ & \\
\hline $\mathrm{Hn}$ & 7,14 & 3 & 21,62 & 8 & $p \leq 0,05$ \\
\hline Середній & 21,42 & 9 & 40,54 & 15 & 1 \\
\hline $\begin{array}{l}\text { Помірно } \\
\text { високий }\end{array}$ & 38,09 & 16 & 27,02 & 10 & $\mathrm{p} \leq$ \\
\hline Високий & 33,35 & 14 & 10,82 & 4 & $p \leq 0,05$ \\
\hline
\end{tabular}

Примітки: * $-p \leq 0,01 ;{ }^{*}-p \leq 0,05$.

у групі юнаків більшість піддослідних $(38,09 \%)$ має помірно високий рівень мотивації до досягнення успіху, у 33,5\% піддослідних виявлений високий рівень мотивації, у $21,42 \%$ - середній, у $7,14 \%$ - низький.

у групі дівчат-футболісток переважає середній рівень мотивації. Він становить 40,54\%. 21,62\% дівчат мають низький рівень мотивації до досягнення успіху, $27,02 \%$ - помірно високий, 10,82\% - високий рівень. Отже, можна побачити за отриманими результатами різницю в групах випробовуваних у досягненні цілей з урахуванням статі спортсменів. Група юнаків-футболістів більше мотивована на успіх, ніж група дівчат.

Розглянемо результати дослідження за методикою «Рівень суб'єктивного контролю (РСК)» Дж. Роттера. У даній методиці ми вважали за доцільне дослідити три шкали з семи можливих, а саме: шкалу інтернальності у сфері досягнень, шкалу інтернальності у сфері невдач і шкалу загальної інтернальності. У табл. 2 відображені показники інтернальності у сфері досягнень.

Високі показники за цією шкалою (табл. 2), зокрема 100\% випробовуваних першої групи та 67\% - другої, відповідають високому рівню суб'єктивного контролю над емоційно-позитивними подіями та ситуаціями. Такі спортсмени вважають, що вони досягли всього хорошого, що було і $\epsilon$ в їхньому житті, і що вони здатні досягти мети в майбутньому.

Низький показник за цією шкалою виявився у групи випробовуваних дівчат (30\%). Такий показник свідчить про те, що людина приписує свої успіхи, досягнення та радості зовнішнім обставинам - везінню, щасливій долі чи допомозі інших людей. У табл. 3 ми бачимо показники інтернальності у сфері невдач.

Розподіл показників за шкалою Таблиця 2 інтернальності у сфері досягнень у двох групах спортсменів

\begin{tabular}{|c|c|c|c|c|c|}
\hline \multirow{2}{*}{$\begin{array}{c}\text { Інтернальність } \\
\text { у сфері } \\
\text { досягнень }\end{array}$} & \multicolumn{2}{|c|}{$\begin{array}{l}\text { Юнаки } \\
(n=42)\end{array}$} & \multicolumn{2}{|c|}{$\begin{array}{c}\text { Дівчата } \\
(n=37)\end{array}$} & \multirow{2}{*}{$\begin{array}{c}\text { Достовір- } \\
\text { ність } \\
\text { відмінностей }\end{array}$} \\
\hline & $\%$ & $\mathbf{n}$ & $\%$ & $\mathbf{n}$ & \\
\hline Екстер & 0 & 0 & 30 & 20 & \\
\hline Інтернальність & 100 & 60 & 67 & 40 & $p \leq 0,01$ \\
\hline
\end{tabular}

Таблиця 3

Розподіл показників за шкалою
інтернальності у сфері невдач
у двох групах спортсменів

\begin{tabular}{|c|c|c|c|c|c|}
\hline \multirow{2}{*}{$\begin{array}{c}\text { Інтернальність } \\
\text { у сфері } \\
\text { досягнень }\end{array}$} & \multicolumn{2}{|c|}{$\begin{array}{l}\text { Юнаки } \\
(\mathrm{n}=42)\end{array}$} & \multicolumn{2}{|c|}{$\begin{array}{c}\text { Дівчата } \\
(\mathrm{n}=37)\end{array}$} & \multirow{2}{*}{$\begin{array}{c}\text { Достовір- } \\
\text { ність } \\
\text { відмінностей }\end{array}$} \\
\hline & 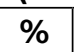 & & 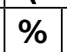 & & \\
\hline & & & & & \\
\hline & 9 & & & & \\
\hline
\end{tabular}

Успішне вирішення завдань фізичної підготовки та спортивного тренування, навчання, виховання та управління також визначається вмінням акцентуватися на положеннях індивідуального підходу, які полягають у знанні індивідуальних особливостей спортсменів. Отримання відповідної психодіагностичної інформації відкриває певні можливості для відбору спортсменів і комплектування спортивних команд.

Ще один фактор, який впливає на рівень тривожності, - це стать випробовуваних. Результати проведеного дослідження показали, що дівчата-футболістки тривожніші, ніж спортсмени-юнаки (табл. 4).

Таблиця 4

Статевий диморфізм у прояві особистісної тривожності студентів-Футболістів

\begin{tabular}{|l|c|c|c|}
\hline \multirow{2}{*}{ Стать піддослідних } & \multicolumn{3}{|c|}{ Тривога (\%) } \\
\cline { 2 - 4 } & висока & середня & низька \\
\hline дівчата & 52 & 40 & 4 \\
\hline юнаки & 25 & 65 & 10 \\
\hline
\end{tabular}

У табл. 4 видно, що високий рівень занепокоєння і тривожності $€$ характерною особливістю дівчат.

Були виявлені статеві особливості розвитку особистісної тривожності. У дівчат-спортсменок рівень тривожності вищий порівняно з юнаками. Відмінність $€$ статистично значущою.

Найбільш ідентичними $€$ співвідношення структур особистості не чоловіків чи жінок, а маскулінних та фемінінних особистостей. Статева ознака тут не має першорядного значення. 
Аналіз структури особистості спортсменів різних класифікаційних груп видів спорту залежно від ґендерного типу дозволив виявити, що найбільш подібною є структура особистості спортсменів, однакових за ґендерним типом, а не за статевою ознакою.

Отримані результати можуть бути використані тренерами у практичній роботі для індивідуалізації навчально-тренувальної діяльності з метою підвищення якості підготовки та результативності виступів на змаганнях.

Подальші дослідження у цьому напрямі будуть спрямовані на вивчення занять баскетболом та футболом ґендерно диференційованих дівчат та юнаків з урахуванням кваліфікації спортсменів.

\section{ЛITEPATУРА:}

1. Артамонова Т.В., Шевченко Т.А. Гендерная идентификация в спорте : монография. Волгоград : ФГОУ ВПО «ВГАФК», 2009. С. 7-8.

2. Багадирова С.К. Формирование гендерной идентичности в условиях профессионализации личности в спорте. Вестник Адыгейского государственного университета. Серия «Педагогика и психология». 2014. Вып. 2. С. 114-119.

3. Бугаевский, К.А. Изучение показателей гендерной идентификации у девушек-спортсменок. Актуальные научные исследования в современном мupe. 2017. № 29. С. 144-153.

4. Ворожбитова А.Л. Гендерная теория фризической культуры как основа фрормирования гендерного сознания спортсменов. Вестник Ставропольского государственного университета. 2007. № 49. C. 27-31.

5. Дамадаева А.С. Психология гендерного развития личности спортсмена : авторефр. дисс. ... докт. психол. наук : 19.00.01. Москва, 2013. 20 с.

6. Жуина Д.В., Майдокина Л.Г. Психологические особенности спортсменов-победителей. Современ- ные проблемы науки и образования. 2014. № 6. URL: https://science-education.ru/ru/article/view?id=15781 (дата обращения: 23.10.2021).

7. Макушина О.П., Щербакова И.В. Гендерные особенности самоактуализации личности в современном обществе. Личность, семья и общество. Серия «Вопросы педагогики и психологии». 2014. № 37 (2). C. 52-57.

8. Тарасевич Е.А. Гендерные отличия спортсменов в различных классисрикационных группах видов спорта и спортивных дисциплин. Слобожанський науково-спортивний вісник. 2016. № 2 (52), C. 117-120.

9. Тарасевич Е.А., Камаев О.И. Гендерные различия в оценке роли занятий спортом как один из показателей качества жизни спортсменов. Фізична активність і якість життя людини : збірник тез доповідей II Міжнародної науково-практичної конореренції, м. Луцьк / Східноєвропейський національний університет імені Лесі Українки. Луцьк. 2018. С. 71.

10. Тарасевич О.А., Камаєв О.І. Особливості ґендерних відмінностей у спортсменів, що займаються спортивними єдиноборствами. Єдиноборства. 2019. № 4 (14). C. 117-126.

11. Цикунова Н.Г. Гендерные характеристики личности спортсменов в маскулинных и фремининных видах спорта : дисс. ... канд. пед. наук : 13.00.04. Санкт-Петербург, 2003. С. 106-108.

12. Смоляр И.И. Личностный аспект лидерства в мужских и женских спортивных командах. Педагогіка, психологія та медико-біологічні проблеми фрізичного виховання і спорту : збірник наукових праць Харківської державної академії дизайну і мистецтв. 2006. № 6. С. 106-108.

13. Сигал Н.С. Влияние типологических свойств нервной системы, темперамента и личностных особенностей на саморегуляцию психических состояний футболистов в командах. Педагогіка, психологія та медико-біологічні проблеми фрізичного виховання і спорту : збірник наукових праць Харківської державної академії дизайну і мистецтв. 2006. № 7. С. 109. 